\title{
KONSELING INDIVIDU MELALUI CYBER COUNSELING TERHADAP PEMBENTUKAN KONSEP DIRI PESERTA DIDIK
}

\author{
Sukoco KW \\ Prodi Bimbingan dan Konseling, FKIP, Universitas Pancasakti Tegal, drssukocokw@gmail.co.id \\ M.Arif Budiman $\mathbf{S}$ \\ Prodi Bimbingan dan Konseling, FKIP, Universitas Pancasakti Tegal, arifups88@gmail.com
}

\begin{abstract}
Abstrak
Konsep diri yang rendah akan mengganggu potensi perkembangan peserta didik. Konsep diri yang rendah diperkirakan berasal dari kurangnya layanan konseling bagi peserta didi Program layanan bimbingan konseling individu dengan pola yang lama perlu dirubah menggunakan model konseling individu melalui cyber conseling. Tujuan penelitian ini yaitu untuk mengetahui layanan konseling individu melalui cyber conseling, pembentukan konsep diri peserta didik melalui cyber conseling dan mengetahui pengaruh konseling individu melalui cyber conseling terhadap pembentukan konsep diri. Jenis penelitian ini adalah penelitian deskriptif korelasional dengan pendekatan kuantitatif non ekspreimen dengan analisis korelasi product moment. Berdasarkan hasil analisis data diperoleh nilai $\mathrm{r} x \mathrm{y}=0,988$. Hasil tersebut kemudian dikonsultasikan dengan $r$ tabel dengan jumlah responden $\mathrm{N}=30$ taraf signifikan 5\% ternyata nilai $\mathrm{r}$ xy lebih besar dari $\mathrm{r}$ tabel yaitu 0,988 $>0,361$. Konseling Individu Melalui Cyber Counseling Terhadap Pembentukan Konsep Diri Peserta didik di Kelas XI SMA Negeri 1 Ketanggungan Kabupaten Brebes" dinyatakan diterima.
\end{abstract}

Kata Kunci : Cyber Conseling, Konseling individu dan Konsep diri.

\begin{abstract}
Low self-concept would interfere with the potential development of learners. Low self-concept can be expected to come from the lack of services for learners. individual counseling services program with the old patterns need to be changed using the model of individual counseling through cyber Counseling. The purpose of this study is to determine the service life of individuals through cyber counseling Counseling, Establishment of the concept of self-pesrta students through cyber Counseling and determine the effect of individual counseling through cyber Conseling towards the formation of self-concept. This type of research is descriptive correlational with non Experimental quantitative approach with product moment correlation analysis. Based on the analysis above, the value of $\mathrm{r} x y=0.988$. The results are then consulted with $\mathrm{r}$ table with the number of respondents $\mathrm{N}=30$ significant level of 5\% turned out to be the value of $\mathrm{r} x \mathrm{x}$ is bigger than $\mathrm{r}$ table is 0.988> 0.361. Individual counseling Counseling Against Cyber Formation Through Self Concept Students in Class XI SMAN 1 Ketanggungan Brebes "are accepted.

Keywords: Cyber Counseling, individual counseling and self-concept.
\end{abstract}

\section{PENDAHULUAN}

Perkembangan Teknologi dan Informasi di era milenial terutama dalam bidang komunikasi memberikan pengaruh yang sangat besar bagi dunia bimbingan dan konseling. Komunikasi sangat diperlukan guna membantu layanan bimbingan konseling melalui berbagai media seperti telepon, komputer, internet, email, websites dan sebagainya. Dengan bantuan media sangat memudahkan guru bimbingan dan konseling dalam memberikan layanan untuk mengembangkan potensi peserta didilk. Namun penggunaan situs jejaring sosial layaknya Twitter, Instagram, MySpace, facebook juga dapat memberikan dampak buruk terhadap perkembangan potensi peserta didik.
Facebook termasuk media sosial dimana dalam penggunaanya user dapat bergabung dalam komunitas seperti pekerjaan, sekolah, organisasi dan bisnis untuk melakukan koneksi dan berinteraksi melalui dunia maya dengan banyak orang. Dalam penggunannya kita juga dapat menambahkan teman-teman, mengunggah status, foto, video, bertukar informasi, dan melengkapi data diri supaya orang lain dapat melihat profil kita. Informasi yang dibagikan memudahkan dan membantu orang menemukan di dalam daftar pencarian. Dengan begitu kita bisa bergabung dalam suatu organisasi sekolah, bisnis, game dan lain lain.

Kemudahan dalam pengguanaan facebook juga dapat memudahkan kinerja guru bimbingan dan konseling 
dalam memberikan layanan untuk pengembangan kepribadian dan potensinya (bakat minat dan kemampuannya). Kepribadian adalah sikap yang dapat diukur oleh sesorang berdasarkan cara beraksi dan berinteraksi. Terbentuknya kepribadian dan kemampuan yang dimiliki peserta didik merupakan gambaran mutu bimbingan dan konseling. Konsep diri menurut banyak ahli psikologi dan pendidikan merupakan salah satu faktor non intelektual penting dan dapat memberikan dampak positif dari prestasi belajar.

Proses pendidikan di SMA, berprestasi secara akademik dan non akademik merupakan harapan dan impian bagi setiap peserta didik. Terkadang peserta didik merasa tidak mampu dalam mengikuti pelajaran matematika sedangkan peserta didik lain merasa tidak akan dapat memperoleh nilai baik dalam pelajaran bahasa inggris. Dari hasil pengamatan sebetulnya peserta didik tidak membicarakan pada dirinya sendiri melainkan apa yang diucapkan menunjukan peserta didik menilai dirinya yang tidak mempunyai kemapuan yang cukup. Supaya perasaan peserta didik yang negatif terhadap kemampuan kualitas diri tidak berlarut-larut dan dapat berakibat buruk maka perlu diberikan penanganan yang tepat dan sesuai berdasarkan gejala-gejala tersebut. Sedangkan proses bimbingan dan konseling di sekolah terbentur adanya keterbatasan waktu dalam pemberian layanan langsung oleh karena itu perlu adanya konseling individu melalui Cyber Counseling yang merupakan salah satu alternatif metode yang dianggap tepat.

Pengertian Konseling Individu menurut Prayitno (1995) adalah cara konselor atau guru dalam memberikan pertolongan memaluli wawancara kepada peserta didik yang nantinya dihapkan dapat mengatasi masalah yang ada dalam diri peserta didik.

Tujuan Layanan Konseling Individu Menurut Gibson, Mitchell \& Basile (2006:142) menyebutkan tujuan konseling perorangan sebagai berikut: a). Tujuan perkembangan yaitu membantu peserta didik dalam proses pertumbuhan dan perkembangan dan memperhitungkan hal-hal yang mungkin terjadi dalam proses tersebut antara lain perkembangan kehidupan pribadi, sosial, emosional, fisik, kognitif dan lain lain. B). Tujuan pencegahan adalah guru atau konselor memberikan bantuan kepada peserta didik mengantisipasi hal-hal yang tidak diinginkan. C). Tujuan peningkatan adalah guru atau konselor membantu peserta didik dalam mengembangkan kemampuan dan keterampilanya. d). Tujuan perbaikan adalah guru atau konselor membantu pesrta didik menghilangkan perkembanganperkembangan yang tidak diinginkan. e). Tujuan penyelidikan adalah menguji kelayakan tujuan guna memeriksa pilihan-pilihan, pengetesan keterampilan, dan mencoba aktivitas baru dan berbeda dan sebagainya. f).
Tujuan penguatan adalah membantu guru atau konselor membantu peserta didik untuk menyadarkan apa peserta didik telah lakukan, dipikirkan dan dirasakan sudah baik. g) Tujuan kognitif adalah memperoleh kemampuan dasar pembelajaran dan keterampilan kognitif. h). Tujuan fisiologis adalah memperoleh pemahaman dasar serta kebiasaan selalu hidup sehat. i). Tujuan psikologis yakni memberikan bantuan dalam mengembangkan keterampilan sosial, belajar dalam mengontrol emosi, mengembangkan konsep diri positif dan lain-lain.

Menurut Prayitno (2006:4) mengemukakan tujuan khusus konseling ke dalam 5 hal yakni : a). Fungsi pemahaman dapat diperoleh peserta didik dalam memahami berbagai masalah yang dialami secara mendalam dan menyeluruh secara postif dan dinamis. b). Fungsi pengentasan memberikan arahan kepada peserta didik untuk mengembangkan persepsi, sikap dan kegiatan untuk mengentaskan masalah pesrta didik tersebut dengan berdasarkan pemahaman-pemahaman yang didapat peseta didik. c). Fungsi pengembangan/pemeliharaan adalah bagian dari dasar pemahaman dan pengentasan masalah peserta didik. d). Fungsi pencegahan masalah-masalah yang mungkin akan timbul serta akan menambah masalah baru bagi peserta didik. e). Sedangkan fungsi advokasi cara yang dapat digunakan untuk menangani peserta didik yang mendapatkan pelanggaran hak.

Cyber Counseling Menurut Surya (2006:97) mengemukakan bahwa perkembangan teknologi yang pesat memudahkan guru atau konselor dapat berinteraksi dengan peserta didik tanpa tersentuh oleh fisik melalui bantuan media internet secara virtual yang disebut $C y b e r$ conseling. Saat ini, layanan konseling dapat ditawarkan dengan menggunakan "cyber counseling", yakni menggunakan media sosial, seperti: e-mail, whatsapp, dan videocall kepada konseli tanpa harus bertatap muka atau "face to face" dengan para siswa. Jika konselor dan konseli sudah paham akan manfaat dan pentingnya TIK dalam menunjang proses layanan bimbingan dan konseling, maka ke depannya pelaksanaan "cyber counseling" akan lebih memudahkan siswa-siswi dalam mengembangkan karakternya (Sutijono, 2018)

Gambaran peserta didik tentang dirinya yang terbentuk dari sejumlah pengalaman-pengalaman yang didapatkan dari interaksi dengan masyarakat atau lingkungan termasuk dalam gambaran konsep diri. Konsep diri merupakan pengalaman yang didapatkan secara terus menerus dan bukan merupakan sifat bawaan. Konsep diri dapat kita tanamkan sejak dini sebagai dasar yang akan mempengarui tingkah laku di kemudian hari.

Konsep diri merupakan gambaran yang dimiliki seseorang tentang dirinya, yang dibentuk melalui pengalaman-pengalaman yang diperoleh dari interaksi dengan lingkungan. Konsep diri bukan merupakan faktor 
bawaan, melainkan berkembang dari pengalaman yang terus menerus terdiferensiasi. Dasar dari konsep diri individu ditanamkan pada saat-saat dini kehidupan anak dan menjadi dasar yang mempengaruhi tingkah lakunya di kemudian hari.

Setiap individu memiliki perasaan dan tanggapan terhadap dirinya didalam setiap pergaulan manusia, entah itu disadari secara jelas ataupun tidak disadari. The self atau konsep diri adalah anggapan seseorang mempersepsikan dan merasakan tentang dirinya sendiri. Sedangkan konsep diri meliputi, sikap, perasaan penghayatan dan anggapan baik yang disadari maupun tidak yang ada dalam seseorang terhadap dirinya sendri. (Hamzah, 2008:129).

Unsur-unsur konsep diri menurut Fitts dalam Agustiani (2009:139) mengemukakan bahwa konsep diri terbagi menjadi dua dimensi yang pertama adalah Dimensi Internal (internal frame of reference) adalah penilaian yang didasari oleh dunianya sendiri pada dirinya. Yang kedua dimensi eksternal adalah individu menilai dirinya sendiri melalui aktifitas sosial yang dilakukan. Dimensi ini merupakan dimensi yang luas yang berkaitan dengan agama, organisasi dan sekolah dan lain-lain. namun menurut Fitts dimensi ini adalah dimensi yang bersifat umum bagi setiap orang.

Berdasarkan permasalahan tersebut maka tujuan penelitian yang akan dicapai dalam penelitian ini adalah: a) Untuk mengetahui pelaksanaan konseling individu melalui cyber counseling di kelas XI SMA Negeri I Ketanggungan Kabupaten Brebes.b) Untuk mengetahui pembentukan konsep diri peserta didik melalui cyber counseling di kelas XI SMA Negeri I Ketanggungan Kabupaten Brebes. c) Untuk mengetahui pengaruh konseling individu melalui cyber counseling terhadap pembentukan konsep diri peserta didik di kelas XI SMA Negeri I Ketanggungan Kabupaten Brebes.

\section{METODE}

Jenis penelitian ini adalah penelitian deskriptif korelasional, menggunakan pendekatan kuantitatif, dengan rancangan penelitian yang bersifat non eksperimen, dengan analisis korelasi product moment. Supaya penelitian ini dapat berjalan dengan lanjar, maka perlu ada langkah-langkah yang persiapkan dalam penelitian ini yaitu a) identifikasi masalah, merumuskan masalah dan menemukan tujuan b) menentukan konsep dan hipotesa serta menggali kepustakaan c) menetapkan sampel d) membuat kuesioner e) melakukan pekerjaan lapangan f) mengolah data, g) analisis dan laporan penelitian. Sesuai dengan penelitian survey dengan pendekatan kuantitatif secara korelasional. (Arikunto, 2006:119).
Populasi dalam penelitian ini adalah peserta didik kelas XI SMA Negeri 1 Ketanggungan, Kabupaten Brebes, yang memiliki konsep diri rendah berjumlah 30 peserta didik. Proses Pendidikan yang dijalani Siswa di SMA Negeri 1 Ketanggungan berasal dari guru yang sama, namun data yang ada siswa tersebut memiliki rasa percaya diri yang rendah. Hal ini tercermin dari rendahnya partisipasi mereka dalam proses pembelajaran secara aktif.

Peneliti akan melakukan penelitian populasi yaitu mengambil semua subyek yang akan diteliti karena jumlahnya kurang dari 100. Jadi populasi pada penelitian ini sebanyak 30 peserta didik yang memiliki konsep diri rendah kelas XI SMAN 1 Ketanggungan Kabupaten Brebes.

Ada 3 metode pengumpulan data yang digunakan dalam penelitian antara lain yaitu metode angket sebagai metode utama dan metode wawancara serta dokumentasi sebagai metode pelengkap. Ketiga metode di atas digunakan untuk mencari pengaruh konseling individu melalui cyber counseling terhadap pembentukan konsep diri peserta didik di kelas XI SMA N 1 Ketanggungan Kabupaten Brebes. Angket terdiri dari 40 item pernyataan, 20 item konseling individu melalui cyber counseling dan 20 item pernyataan tentang pembentukan konsep diri peserta didik. Untuk menguji angket sebelum digunakan dalam penelitian maka angket perlu terlebih dahulu diuji cobakan pada sekolah yang berbeda yaitu di SMA N 1 Bulakamba Kabupaten Brebes kelas XI untuk mendapat hasil validitas dan reliabilitas. Berdasarkan hasil uji coba dari 40 item tersebut memperoleh hasil valid semua dan koofisien reliabilitas dari variabel $\mathrm{X}$ adalah 0,908 dan variabel $\mathrm{Y}$ adalah 0,873 , sehingga dari hasil tersebut bisa dikatakan reliabel. Penelitian ini menggunakan Teknik analisis data korelasi product moment serta analisis deskriptif korelasi. Sedangkan uji hipotesis menggunakan rumus angka kasar (korelasi product moment).

\section{HASIL DAN PEMBAHASAN}

Hasil Penelitian

Hasil uji validitas Konseling Individu melalui Cyber Counseling menggunakan aplikasi MS Excel 2007 menyatakan bahwa pada soal no. 1 menghasilkan nilai $r$ hitung sebesar 0,364 sedangkan $\mathrm{r}$ tabel untuk $\mathrm{N}=30$ sebesar 0,361 karena $r$ hitung $>r$ tabel atau 0,364 > 0,361, maka dinyatakan bahwa item no. 1 adalah valid. Demikian juga perhitungan selanjutnya sampai butir 20 . Dengan demikian instrumen ini sudah layak digunakan untuk alat pengumpulan data.

Sedangkan hasil uji validitas Instrumen Konsep diri peserta didik pada soal item no. 1 menghasilkan nilai $r$ hitung sebesar 0,418 sedangkan $\mathrm{r}$ tabel untuk $\mathrm{N}=30$ sebesar 0,361 karena $r$ hitung $>r$ tabel atau 0,418>0,361 
maka dinyatakan bahwa item no. 1 adalah valid, demikian juga perhitungan selanjutnya sampai butir ke 20.

Uji reliabilitas Instrumen Konseling individu melalui cyber counseling dianggap reliabel atau memiliki tingkat reliabel tinggi, karena terletak antara 0,91-1,00, sehingga angket tersebut dapat digunakan sebagai alat pengumpul data. Dari hasil try out angket Konsep Diri Peserta didik memiliki hasil reliabilitas sebesar 0,873, sehingga dinyatakan $\mathrm{r} 11>$ rtabel atau 0,873 > 0,361 maka pada angket variabel $\mathrm{Y}$ yaitu Konsep Diri Peserta didik dianggap reliabel atau memiliki tingkat reliabel tinggi, karena terletak 0,71-0,90, dengan demikian angket ini sudah layak digunakan untuk alat pengumpulan data.

Hasil penelitian tentang Konseling Individu Melalui Cyber Counseling di Kelas XI SMA Negeri 1Ketanggungan Kabupaten Brebes termasuk dalam kategori sangat rendah berjumlah 1 peserta didik persentase $(3 \%)$, kategori rendah berjumlah 5 peserta didik persentase (16\%), kategori cukup sebanyak 8 peserta didik persentase (27\%), kategori tinggi berjumlah 12 peserta didik persentase $(40 \%)$, dan kategori sangat tinggi berjumlah 4 peserta didik dengan pencapaian persentase (14\%).

Tabel.1 Distribusi Frekuensi Variabel Konseling Individu Melalui Cyber Counseling

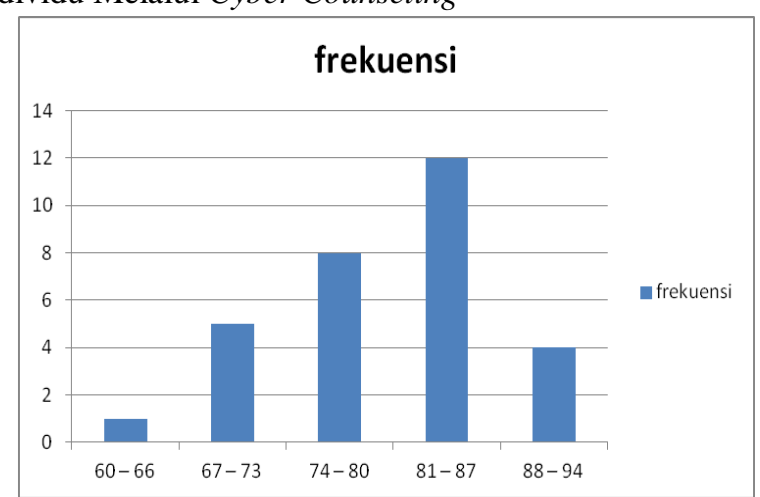

Berdasarkan data hasil penelitian tentang Konsep Diri Peserta didik di Kelas XI SMA Negeri 1 Ketanggungan Kabupaten Brebes termasuk dalam kategori sangat rendah berjumlah 1 peserta didik dengan persentase (3\%), kategori rendah berjumlah 6 peserta didik dengan persentase (20\%), kategori cukup sejumlah 9 peserta didik persentase $(30 \%)$, kategori tinggi berjumlah 11 peserta didik persentase (37\%), dan kategori sangat tinggi berjumlah 3 peserta didik dengan persentase (10\%).

Tabel.1 Distribusi Frekuensi Distribusi Frekuensi Variabel Konsep Diri Peserta didik

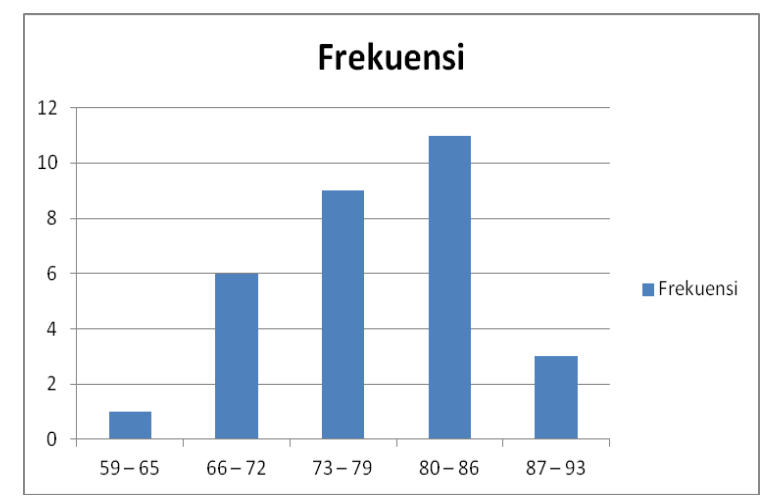

Berdasarkan hasil analisis data diatas, diperoleh nilai $\mathrm{r}$ $\mathrm{xy}=0,988$. Hasil tersebut kemudian dikonsultasikan dengan $r$ tabel dengan jumlah responden $\mathrm{N}=30$ taraf signifikan $5 \%$ ternyata nilai $\mathrm{r}$ xy lebih besar dari $\mathrm{r}$ tabel yaitu $0,988>0,361$.

Pembahasan Penelitian

Berdasarkan hasil diatas, diperoleh nilai r xy $=0,988$. Hasil tersebut kemudian dikonsultasikan dengan $r$ tabel dengan jumlah responden $\mathrm{N}=30$ taraf signifikan 5\% ternyata nilai $\mathrm{r}$ xy lebih besar dari $\mathrm{r}$ tabel yaitu $0,988>$ 0,361 . Dengan analisa data tersebut, ini berarti Hipotesis nihil Ho yang berbunyi "Konseling Individu Melalui Cyber Counseling Terhadap Pembentukan Konsep Diri Peserta didik di Kelas XI SMA Negeri 1 Ketanggungan Kabupaten Brebes dinyatakan ditolak dan sebaliknya Hipotesis Kerja Ha yang berbunyi "Konseling Individu Melalui Cyber Counseling Terhadap Pembentukan Konsep Diri Peserta didik di Kelas XI SMA Negeri 1 Ketanggungan Kabupaten Brebes" dinyatakan diterima.

Dengan demikian telah terbukti dan benar-benar menunjukkan "Terdapat Pengaruh antara Konseling Individu Melalui Cyber Counseling Terhadap Pembentukan Konsep Diri Peserta didik di Kelas XI SMA Negeri 1 Ketanggungan Kabupaten Brebes”.

\section{PENUTUP}

\section{Simpulan}

Konseling individu melalui cyber counseling, ditemukan data sebagai berikut 30 peserta didik menunjukkan angka ketercapaian dengan kriteria sangat tinggi sehingga layanan konseling individu melalui cyber counseling terhadap pembentukan konsep diri peserta didik pada dasarnya tergolong tinggi, peserta didik lebih percaya diri dengan adanya cyber counselig dan bisa menyikapi permasalahan yang dihadapinya dengan baik.

Pembentukan konsep diri peserta didik melalui cyber counseling telah terlaksana dengan baik. Ditemukan data sebagai berikut 30 peserta didik menunjukkan angka ketercapaian kriteria sangat tinggi sehingga pembentukan konsep diri peserta didik melalui cyber counseling di sekolah pada dasarnya tergolong tinggi. 
Hasil korelasi kedua variabel dengan rumus korelasi product momen, didapatkan nilai $\mathrm{r}$ xy sebesar 0,988 dengan jumlah peserta didik $\mathrm{N}=30$ yang menggunakan taraf signifikan $5 \%$ ternyata nilai $\mathrm{r}$ xy lebih besar dari $\mathrm{r}$ tabel yaitu 0,988>0,361. Jadi simpulannya adalah Terdapat Pengaruh Konseling Individu Melalui Cyber Counseling Terhadap Pembentukan Konsep Diri Peserta didik di Kelas XI SMA Negeri 1 Ketanggungan Kabupaten Brebes".

\section{Saran}

Berdasarkan hasil penelitian yang menunjukkan bahwa pengaruh konseling individu melalui cyber counseling dalam kriteria tinggi, disarankan agar konselor tetap mendukung dan mempertahankan layanan konseling individu melalui cyber counseling.

Pembentukan konsep diri peserta didik dalam kriteria tinggi diharapkan agar peserta didik mempertahankan konsep diri yang telah dicapai dengan baik dan tidak segan-segan meminta bantuan kepada guru bimbingan dan konseling yaitu melalui media internet atau facebook apabila memiliki permasalahan agar lebih leluasa dalam mengungkapkan permasalahan yang dihadapinya.

Pengaruh konseling individu melalui cyber counseling terhadap pembentukan konsep diri peserta didik tergolong tinggi, disarankan agar pihak sekolah selalu mendukung kegiatan konseling individu melalui cyber counseling terutama dalam hal sarana dan prasarana yang memadai serta pengalokasian waktu guna pelaksanaan konseling individu melalui cyber counseling agar dapat berjalan dengan lancar.

\section{DAFTAR PUSTAKA}

Agustiani, H. 2009. Psikologi Perkembangan (Pendekatan Ekologi Kaitannya dengan Konsep Diri dan Penyesuaian Diri pada Remaja). Bandung: Rafika.

Aksara, Agustiani, Hendriati. 2009. Psikologi Perkembangan. Bandung : Refika Aditama.

Arikunto, Suharsimi. 2006. Prosedur Penelitian Suatu Pendekatan Praktek. Jakarta: Rineka Cipta.

B, Uno, Hamzah. 2008. Teori Motivasi dan Pengukurannya, Jakarta : Bumi

Gibson,R L; Mitchell, Marianne H. 2011. Bimbingan dan Konseling (Edisi Indonesia-Edisi ke Tujuh). Yogyakarta:Pustaka Pelajar.

B. Uno, Hamzah. 2008. Teori Motivasi dan Pengukurannya, Jakarta : Bumi. Aksara. BSNP. 2006. Standar isi untuk satuan pendidikan dasar dan menengah.

Prayitno, Errman Amti. 2006. Dasar-dasar Bimbingan dan Konseling. Jakarta :Rineka Cipta.

Prayitno. 1995. Layanan Bimbingan dan Konseling Kelompok Dasar Dan Profil.Jakarta : Ghalia Indonesia.

Surya, Mohamad. 2009. Kongres ABKIN XI.

Sutijono, S., \& Farid, D. A. M. (2018). Cyber counseling di era generasi milenial. SOSIOHUMANIKA, 11(1), 19-32. 